\title{
Organisational Justice and Employees' Engagement Towards Turnover Intention. An Explanatory Study Among Hospital Employees in Malaysia
}

\author{
Mohamad Ariffin Adollahdin, Ibiwani Alisa Hussain* \\ School of Management, Faculty of Business and Management, Asia Pacific University of Technology and Innovation, Bukit Jalil, Kuala \\ Lumpur, Malaysia
}

Email address:

mhamadariffinadollahdin@hotmail.com (M. A. Adollahdin), dr. ibiwani@apu.edu.my (I. A. Hussian)

${ }^{*}$ Corresponding author

To cite this article:

Mohamad Ariffin Adollahdin, Ibiwani Alisa Hussain. Organisational Justice and Employees' Engagement Towards Turnover Intention. An Explanatory Study Among Hospital Employees in Malaysia. European Business \& Management. Vol. 5, No. 6, 2019, pp. 79-83. doi: 10.11648/j.ebm.20190506.12

Received: October 12, 2019; Accepted: November 18, 2019; Published: November 22, 2019

\begin{abstract}
This study investigated organisational justice and employees' engagement's effect towards turnover intention among hospital employees in Malaysia. Primary data was used and obtained through self-administered survey questionnaire distributed manually to 100 respondents. This study developed hypothesis based on past research conducted and the hypothesis was tested to examine the relationship between predictors and the dependent variables. Using one analysis, i.e. Correlation analysis was conducted to ascertain the hypothesis and findings from the analysis revealed a weak positive but reverse significant relationship between predictors and dependent variable. Findings explained that both organisational justice and employees' engagement demonstrated a low significant relationship towards turnover intention. Interestingly, this study found a reversed relationship between predictors and dependant variable. One unit increase in organisational justice resulted in one unit decrease in turnover intention and one unit increase in employee engagement also resulted in one unit decrease in turnover intention. The findings served as one of the important platforms for hospital's management to understand the reasons of employees quitting or changing jobs in the perspective of organisational justice and employees' engagement. Based on the findings, Management may embark on further improvement or enhancement is necessary for hospitals to embrace in reducing the intention to leave among hospital employees in Malaysia.
\end{abstract}

Keywords: Organisational Justice, Employee Engagement, Turnover Intention, Hospital Employees

\section{Introduction}

Hospital workers are considered as an important resources for every hospital guaranteeing the operation to run smoothly. The hospital alone, may not be able to convey their best execution to accomplish their goals and objectives. One of the challenges for the hospitals is employee turnover. The turnover rate has begun to pick up what's coming to it's of consideration. Areas to consider relating to turnover are feeling of being justly treated which contribute towards employee feeling engaged in the organisation [1].

Organisational justice is a worker's impression of the decency of asset allotment in an association [2]. This is alluding to management's choices and activities that are ethically right as per moral gauges, religion or law. Partitions of organisational justice is conceptualised into three measurements that are procedural justice, distributive justice and interactional justice [2].

Worker's engagement is a positive, satisfying, businessrelated perspective that is portrayed by life, commitment, and assimilation [3]. While Kahn [4] portrayed engagement as the saddling of individuals' selves to their work, to such an extent that they completely contribute their of individuals' selves to their work, completely contribute to their physical, subjective, and passionate assets in their work parts. It was contended that having somewhat alternate points of view there are centre shared traits between the conceptualisations and measures of engagement [3,4]. Therefore, the objective 
of this study is to examine dimensions in organisational justice and employee engagement construct towards turnover intention among hospital employees in Malaysia.

\section{Antecedents of Turnover Intention}

When workers genuinely consider stopping their occupations, they are thought to stop working at the organisation. The expression "intention" portrays a worker's want or deliberateness to leave the organisation. Turnover intention, a solid indicator of stopping from the organisation, turns into a last advance before a worker really leaves the organisation. The estimation of this develop frequently involves utilising a specific timeframe. The idea behind utilising this interim as an estimation is that workers turnover intention is a tedious procedure [5]. There are various variables that influenced a worker's intention to leave particularly for hospital employees [6]. They incorporate an employee's state of mind and potential, appraiser, peers, management, hierarchical arrangement, outside occupation requests, worker's own evaluation of employment-related authoritative choice, pay, work fulfilment, association, involvement in the association, statistic factors, family measure, confide in, duty and others, work improvement and employment soundness, work prospects, worker engagement, pay, development and advancement, positive sentiments and trust, social help of the manager and hierarchical legislative issues may make a behavioural inclination hold the enrolment or pull back from the association and to judge if a specific occupation can fulfil his or her desires [7].

\subsection{Organisational Justice}

Organisational justice has been dependably a human and authoritative concern not just on account of its advantages to the organisation yet additionally the negative outcomes that may hurt the organisation if there should arise an occurrence of foul play [8]. The significance of organisational justice increments in creating nations where assets are constrained and touchy to any adjustment in compensation and rephrases [8], which makes organisational justice a basic factor to look after employees. Organisational justice is viewed as the apparent decency inside an authoritative setting with three measurements that are distributive, procedural and interactional justice [9].

\subsubsection{Distributive Justice}

Distributive justice is characterised by the level of justice and just in the appropriation of reward in the organisation Previous study found that distributive justice is alluded to as the worker singular judgment and observation towards the conveyance of rewards, for example, payment and advancement by the management [10]. It was also found that the absence of distributive justice de-inspire and release the spirit of the worker and take steps to lack of satisfaction. Distributive justice is the still, small voice and adjust during the time spent sharing employees' rewards even-handedly and decently in understanding to their activity execution and is essential as the framework that guarantees exceedingly dedicated and performing employee get a high reward and the other way around [11].

\subsubsection{Procedural Justice}

Procedural justice has alluded to the process and methods took after to choose employee rewards [12]. It was found that the procedural justice definition, by adding that it brings up to the observation and how to satisfy worker's feel as far as association management choices and assurance of reward dissemination and assets dispersion [12]. Procedure and the assurance of reward appropriation on occasion concerns worker than the circulation itself, as the conveyance takes after the system dictated by the organisation. Subsequently, higher impression of procedural justice by employees will probably respond with more noteworthy authoritative engagement toward worker expectation to stay and the employees' certain assessment of their supervisor [12], thusly their vague of basic leadership procedures to workers abuse procedural fairness and loss of trust between the employer and worker relationship leads toward work disappointment [11].

\subsubsection{Interactional Justice}

Interactional justice is how much the general population influenced by choice are dealt with by nobility and regard. It is isolated into two sections i.e., interpersonal justice and informational justice. Interpersonal justice is characterised as the manner by which a man is dealt with by his bosses, subordinates and so on. Treatment by a boss is characterised as regard, poise, inspiration, consolation and so on. Informational justice is characterised as the clarifications gave to individuals that pass on data concerning why strategies were utilised as a part of a specific way or why results were circulated in a specific form [12]. Informational justice grandstands the straightforwardness in the techniques received to accomplish certain choice or result.

\subsection{Employee Engagement}

The verb 'to engage' has numerous indications, shifting from a clear passionate condition of being 'in equipping', that is being included and submitted, to another value-based condition of working as an end-result of a reasonable transactional trade at working environment [3]. Worker engagement reflected the developing significance of human capital and mental contribution of workers in the business. Organisations must choose the option to deliver more yield with less worker input. In endeavouring to do such, organisations need to connect with the physical body, as well as the psychological personality and the natural soul of each individual worker.

The idea of engagement as a multi-dimensional build was first presented by [4], the scholastic pioneer of the worker engagement development. The individual engagement was characterised as the outfitting of employees' selves to their work parts where they convey what needs be physically, intellectually and candidly amid part exhibitions. Kahn's 
model was then tried, and discoveries bolstered that the mental states of importance, wellbeing and accessibility are decidedly connected to engagement [4].

Later, Saks' far-reaching model on predecessors and outcomes of occupation engagement (work part), and association engagement (employees' part as individuals from an association) was tried and approved.

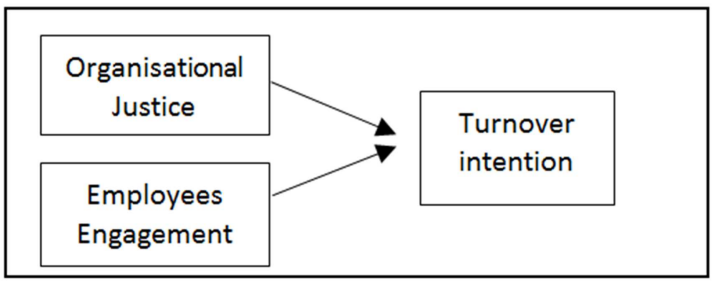

Figure 1. The overall conceptual framework.

The overall conceptual framework for this study is depicted in figure 1 above.

\section{Methodology}

This study is an explanatory study which uses primary data, gathered using self-administered survey questionnaire. Unit of analysis for the study was hospital employees in
Malaysia. Survey questionnaire was distributed manually through convenient sampling method. The study was able to obtain a total of 100 respondents for the purpose of data analysis.

Instruments for survey questionnaire were adopted and adapted from [1] for turnover intention. While instruments for employees' engagement, the items were adapted from [12] and for organisational justice, were adapted from [13]. Questionnaire were designed in english language and all items in the survey questionnaire were measured using 5 point Likert-Scale Ranging from $1=$ strongly disagree and $5=$ strongly agree.

\section{Findings}

Findings from descriptive analysis found that out of 100 respondents, $49 \%$ were male with $51 \%$ female. On age statistic, the largest respondent, i.e., 40\% was respondents between the age of 20 to 29 years old. On marital status, $72 \%$ respondent were married and denoted the highest. $49 \%$ from the respondents attained Diploma qualification and appear to be the highest on academic background. Majority of the respondents hold position as general worker, denoted by $42 \%$ and only $23 \%$ were the medical officer.

Table 1. below illustrate the descriptive analysis found based on the respondents participated in the study.

\begin{tabular}{|c|c|c|}
\hline \multirow{2}{*}{ Gender } & Male & $49 \%$ \\
\hline & Female & $51 \%$ \\
\hline \multirow{4}{*}{ Age } & $20-29$ & $40 \%$ \\
\hline & $30-39$ & $33 \%$ \\
\hline & $40-49$ & $22 \%$ \\
\hline & 50 and above & $5 \%$ \\
\hline \multirow{3}{*}{ Marital status } & Single & $27 \%$ \\
\hline & Married & $72 \%$ \\
\hline & Divorced & $1 \%$ \\
\hline \multirow{4}{*}{ Education } & Secondary School & $22 \%$ \\
\hline & Diploma & $49 \%$ \\
\hline & Bachelor Degree & $21 \%$ \\
\hline & Postgraduate Degree & $8 \%$ \\
\hline \multirow[b]{2}{*}{ Department in hospital } & Medical Officer & $23 \%$ \\
\hline & Administrative Staff & $35 \%$ \\
\hline
\end{tabular}

The summary on frequency analysis conducted on organisational justice found that $55 \%$ agreed that their workload is fair and $51 \%$ said that they received fairness of overall rewards. Finally $54 \%$ agreed on their feelings toward job responsibilities. While on employee engagement, frequency analysis on the items discovered that $35 \%$ disagreed that the job decisions made by the manager are in a biased manner, $63 \%$ were neutral on manager attitudes that make sure all employee's concern are heard before job decisions are made, $52 \%$ agreed that they have friends at the workplace. In contrary, on intention to leave, $34 \%$ were neutral on looking for a new job in the next and another $34 \%$ agreed that they often think of changing their job.

Table 2. below illustrate the frequency analysis found on predictors and dependent variable.

\begin{tabular}{|c|c|c|c|c|c|c|}
\hline No & organisational justice & $1(\%)$ & $2(\%)$ & $3(\%)$ & $4(\%)$ & $5(\%)$ \\
\hline 1 & My work schedule is fair. & & 5 & 29 & 53 & 13 \\
\hline 2 & I think that my level of pay is fair. & 2 & 11 & 26 & 53 & 8 \\
\hline 3 & I consider my work load to be quite fair. & & 6 & 32 & 55 & 7 \\
\hline 4 & Overall the rewards I receive here quite fair. & 1 & 5 & 37 & 51 & 6 \\
\hline 5 & I feel that my job responsibilities. & & & 18 & 54 & 28 \\
\hline 6 & Job decisions are made by the manager in a biased manner. & 20 & 35 & 22 & 18 & 5 \\
\hline 7 & My manager makes sure that all employee concerns are heard before job decisions are made. & & 1 & 63 & 32 & 4 \\
\hline
\end{tabular}




\begin{tabular}{|c|c|c|c|c|c|c|}
\hline No & organisational justice & $1(\%)$ & $2(\%)$ & $3(\%)$ & $4(\%)$ & $5(\%)$ \\
\hline 8 & To make job decisions, my manager collects accurate and complete information. & & 5 & 53 & 35 & 7 \\
\hline 9 & $\begin{array}{l}\text { My manager clarifies decisions and provides additional information when requested by } \\
\text { employees. }\end{array}$ & & 2 & 47 & 47 & 4 \\
\hline 10 & Employees are allowed to challenge or appeal job decisions made by their managers. & & 8 & 37 & 51 & 4 \\
\hline 11 & When decisions are made about my job, the manager treats me with respect and dignity. & & 2 & 41 & 45 & 12 \\
\hline 12 & $\begin{array}{l}\text { When decisions are made about my job, the manager shows concern for my right as an } \\
\text { employee. }\end{array}$ & & 4 & 38 & 49 & 9 \\
\hline 13 & $\begin{array}{l}\text { Concerning decisions made about my job, the manager discusses with me the implications of } \\
\text { the decisions. }\end{array}$ & & 3 & 45 & 45 & 7 \\
\hline 14 & The manager offers adequate justification for decisions made about my job. & & 4 & 51 & 37 & 8 \\
\hline 15 & My manager explains very clearly any decisions made about my job. & & 8 & 41 & 43 & 8 \\
\hline \multicolumn{7}{|c|}{ Employee engagement } \\
\hline 1 & I have received recognition for doing my job well. & & 6 & 35 & 39 & 20 \\
\hline 2 & My supervisor seems concerned about my welfare. & 1 & 8 & 40 & 42 & 9 \\
\hline 3 & I have friends at work. & & & 18 & 52 & 30 \\
\hline 4 & While on the job, my ideas and opinions are taken seriously. & & 6 & 32 & 46 & 16 \\
\hline 5 & The people I work with do a good job. & 1 & 4 & 25 & 48 & 22 \\
\hline \multicolumn{7}{|c|}{ Turnover intention } \\
\hline 1 & I often think about quitting. & 24 & 18 & 27 & 27 & 4 \\
\hline 2 & It is likely that I will actively look for a new job next year. & 19 & 19 & 30 & 23 & 9 \\
\hline 3 & I will probably look for a new job in the next. & 21 & 13 & 34 & 24 & 8 \\
\hline 4 & I often think of changing my job. & 24 & 14 & 19 & 34 & 9 \\
\hline
\end{tabular}

Data collected undergone reliability analysis to measure the internal consistency of scale with the samples. Correlation analysis was conducted in the study and revealed that the $\mathrm{r}^{2}$ for organisational justice are valued at -.0 .399 for distributive justice, 0.092 for interactional justice and -0.344 for procedural justice on significant value towards turnover intention among hospital employees in Malaysia. It can be concluded that overall interactional justice contributed the least while distributive justice has the strongest influenced on turnover intention with reverse relationship. On the relationship of employee engagement towards turnover intention, it was found that the relationship is a weak reverse relationship with the $r^{2}$ value of 0.378. Overall, findings from correlation analysis demonstrated a weak reverse relationship between organisational justice and employee engagement towards turnover intention among hospital employees in Malaysia.

Table 3. below illustrate the correlation analysis found on predictors and dependent variable.

\begin{tabular}{|c|c|c|c|c|}
\hline & Employees' Engagement & Procedural Justice & Interactional Justice & Turnover Intention \\
\hline Employees' Engagement & 1 & & & -0.3779 \\
\hline Procedural Justice & & 1 & & 0.0924 \\
\hline Interactional Justice & & & 1 & -0.3441 \\
\hline Turnover Intention & & & & 1 \\
\hline
\end{tabular}

\section{Discussion}

The objective of the study aimed at examining the relationship between dimensions in organisational justice and employee engagement construct towards turnover intention among hospital employees in Malaysia. Results from the statistical tests indicated a reverse significant relationship between predictors and dependent variable. The reverse negative value obtained from the study demonstrated that employees' engagement has small influenced on the intention to leave the organisation and that employee engagement is not a strong factor influencing employees to leave the organisation. This findings could be due to fact respondents are mostly young at age, worked as general workers and are concern on job security due to their employment level. This finding is in the opposite of study conducted by [14] and [15], of which had discovered a significant relationship between same predictors and dependent variable. Their findings found that organizational justice does not have significant affect turnover intention among workers in hospitals. Another study from [16] also found the opposite result and it may be due to the background of the study where it was conducted in a different country and respondents were only female workers.

Based on the conceptual framework for this study, out of the two variables, procedural justice dimension in organisational justice construct contributed the highest influenced towards employee engagement in the perspective of young workers with low level of employment. It shows that proper guidance and policy must be established and communicated to them well in ensuring good comprehension which may influenced high engagement and reduce the intention of leaving the organisation. Workers at lower level in hospitals are very important in the sense that they are the major contributor in executing day-to-day operation in both outpatient and inpatient customers. Therefore, it is imperative for the management of hospitals to address their engagement by applying the model which is found in this study as working ground to curb further intention to leave among the workers. In the nutshell, the objective for the study were met. 


\section{Conclusion}

The study was conducted within Hospitals in Malaysia and found a reverse significant relationship between organisational justice and turnover intention also the same pattern for employee engagement and turnover intention.

Management of hospitals must work towards applying justice in their policies as well as build trust among employees to instil better engagement which may lead to lower employee turnover.

\section{References}

[1] Abdul Latif, F. and Naiemah Saraih, U. (2016). Factors Influencing Employee Turnover in Private Sector In Malaysia: A Concept Paper. Australian Journal of Basic and Applied Sciences, [online] 10 (7). Available at: http://www.ajbasweb.com [Accessed 19 Mar. 2018].

[2] Greenberg, J. (1998). Equity and workplace status: A field experiment. Journal of Applied Psychology, 73, 606-613.

[3] Schaufeli, W. B., \& Salanova, M. (2007). Work engagement: An emerging psychological concept and its implication for organizations. Institute of Psychology, 22, 3, 14-17.

[4] Kahn, W. A. (1990). Psychological conditions of personal engagement and disengagement at work. Academy of Management Journal, 33, 692-724.

[5] Omar, K., Anuar, M., Ahmad, A., Ismail, R. and Din, B. (2015). Nurses' Intention to Leave: Do Demographic Factors Matter?. Journal of Human Resources Management and Labor Studies, [online] 3 (2). Available at: http://dx.doi.org/10.15640/jhrmls.v3n2a4 [Accessed 29 Mar. 2018].

[6] Rahman, W. and Nas, Z. (2013). Employee development and turnover intention: theory validation. [online] www.emeraldinsight.com. Available at: https://scihub.tw/https://www.emeraldinsight.com/doi/abs/10.1108/EJT D-May-2012-0015 [Accessed 26 Mar. 2018].

[7] Macey, W. H., Schneider, B., Barbera, K. M., \& Young, S. A. (2009). Employee Engagement: Tools for Analysis, Practice, and Competitive Advantage. Malden, WA: Wiley-Blackwell.

[8] Colquitt, J. A., Conlon, D. E., Wesson, M. J., Porter, C. O. L.
H., \& Ng, K. Y., (2001). Justice at the millennium: A metaanalytic review of 25 years of organizational justice research. Journal of Applied Psychology, 86, 3, 424-445

[9] Mohamed Badawy, S. and Fathy El-Fekey, S. (2017). Does Social Comparison Orientation Moderate the Organisational Justice, In-role Performance, Citizenship and Counterproductive Behaviours Relationship? International Journal of Business and Management, [online] 12 (12), p.181. Available at: https://doi.org/10.5539/ijbm.v12n12p181 [Accessed 27 Mar. 2018].

[10] Folger, R., \& Konovsky, M. A. (1989). Effects of procedural justice and distributive justice on reactions to pay raise decisions. Academy of Management Journal, 32, 1, 115-130.

[11] Phayoonpun, T. And Mat, N. (2014). ORGANIZATIONAL JUSTICE AND TURNOVER INTENTION: THE MEDIATION ROLE OF JOB SATISFACTION. 2nd Ed. Othman Yeop Abdullah Graduate School Of Business (OYAGSB).

[12] Saks, A. M. (2006). Antecedents and consequences of employee engagement. Journal of Managerial Psychology, 21, $7,600-614$.

[13] Gupta, M. and Shaheen, M. (2017). Impact of work engagement on turnover intention: moderation by psychological capital in India. Business: Theory and Practice, [online] 18 (1), pp.136-143. Available at: http://btp.press.vgtu.lt [Accessed 30 Mar. 2018].

[14] Harter, J. K., Schmidt, F. L., \& Hayes, T. L. (2002). Businessunit-level relationship between employee satisfaction, employee engagement, and business outcomes: A Metaanalysis. Journal of Applied Psychology, 87-268-279.

[15] Sokhanvar, M., Hasanpoor, E., Hajihashemi, S. and Kakemam, E. (2016). The Relationship between Organizational Justice and Turnover Intention: A Survey on Hospital Nurses. Patient Safety and Quality Improvement Journal, [online] 4 (2), pp.358-362. Available at: http://eprints.mums.ac.ir/1845/1/PSJ Volume\%204 Issue $\% 20$ 2_Pages\%20358-362.pdf [Accessed 30 Mar. 2018].

[16] Chhetri, S. (2017). Predictors and Outcomes of Employee Engagement: Empirical Study of Nepali Employees. [online] www.nepjol.info. Available at: http://dx.doi.org/10.3126/jbmr.v2i1-2.18149 [Accessed 28 Mar. 2018]. 